\title{
Paideusis
}

\section{That the First Shall Not Be the Last}

\section{Paul O'Leary}

Volume 1, Number 1, 1987

URI: https://id.erudit.org/iderudit/1071141ar

DOI: https://doi.org/10.7202/1071141ar

See table of contents

Publisher(s)

Canadian Philosophy of Education Society

ISSN

0838-4517 (print)

1916-0348 (digital)

Explore this journal

Cite this document

O'Leary, P. (1987). That the First Shall Not Be the Last. Paideusis, 1(1), 1-2.

https://doi.org/10.7202/1071141ar

This document is protected by copyright law. Use of the services of Erudit (including reproduction) is subject to its terms and conditions, which can be viewed online.

https://apropos.erudit.org/en/users/policy-on-use/ 


\section{Contents}

Editorial

Conceptual Finesse

Robin Barrow

A Taxonomy of Responses and
Respondents to Literature
Deanne Bogdan

Respect for the Law: An

Educational Objective?

Jerrold Coombs

A Review of William Hare's

In Defence of Open-Mindedness

48

Cornel Hamm

\section{Editorial}

\section{That The First Shall Not Be The Last}

Paideusis is produced by the Canadian Philosophy of Education Society in the belief that philosophy of education has reached a level of maturity in this country sufficient to justify a journal devoted to the subject. Its purpose is to stimulate a conspicuous Canadian presence in the field and to facilitate scholarly communication among those seriously interested in philosophy of education. While the journal's focus is philosophical, it will not function as a closed shop in which only those who are "certified" philosophers of education can work. Indeed, we hope that the journal will be read and contributed to by those who, although not formally philosophers of education, are nonetheless drawn to 
philosophical problems by virtue of their work in areas such as curriculum, psychology, law, and sociology. The current issue reflects this hope. In addition to Barrow's conceptualization of conceptual finesse, it contains a piece by Coombs which should interest those concerned with legal education and another by Bogdan which embraces such areas as literary theory, aesthetics, and problems connected with the teaching of literature.

It is a self-evident truth that hope, while clearly a virtue, cannot by itself produce a journal. But there is another virtue that makes survival possible even in these economically hard pressed times. It is the generosity of the institutions listed below that will ensure that this, the first issue of Paideusis, not to be the last.

The University of Alberta

The University of British Columbia

Brock University

Dalhousie University

Univerisité Laval

The University of Lethbridge

Memorial University of Newfoundland

Mount Saint Vincent University

The University of New Brunswick

The Ontario Institute for Studies in Education

The University of Regina

Simon Fraser University

The University of Western Ontario

Paul O'Leary

Editor 